\section{SYNTHETIC STUDIES ON GRATISIN. II}

Sir:

An antibiotic peptide, gratisin, which is active toward Bacillus subtilis was isolated from $B$. brevis Y-33 by Silaev et al. ${ }^{1)}$ It is a cyclododecapeptide composed of two each of Val, Orn, Leu, Phe, Pro and Tyr residues. The primary structure of gratisin was proposed as shown in Fig. $1,{ }^{2,3)}$ but the configurations of the individual amino acid residues have not yet been established. We previously synthesized ${ }^{4}$ all-L-gratisin containing only L-amino acid residues and [D$\mathrm{Phe}^{4,4^{\prime}}$ ]-gratisin containing $\mathrm{D}$-Phe residues in positions 4 and $4^{\prime}$ (Fig. 1), and examined the antibiotic activity of these peptides. The latter compound was synthesized because of the analogy of the primary structure of gratisin with that of gramicidin $\mathbf{S}$ (GS). [D-Phe ${ }^{4,4^{\prime}}$ ]-gratisin has antibiotic activity against all Gram-positive microorganisms tested, but is less potent than GS. On the other hand, all-L-gratisin showed little activity (Table 1). These results suggested that the Phe residue is present in the $\mathrm{D}$-form in gratisin. The configurations of the amino acid residues following the Pro residues remained undetermined. Therefore, we synthesized [D-Phe ${ }^{4,4^{\prime}}, \mathrm{D}-\mathrm{Tyr}^{\mathrm{B}, 8^{\prime}}$ ]gratisin having -D-Phe-Pro-D-Tyr- partial sequence as shown Fig. 1, and investigated the relationship between the structure and antibiotic activity of these synthetic peptides.

[D-Phe $\left.{ }^{4,4^{\prime}}, \mathrm{D}-\mathrm{Tyr}^{8,8^{\prime}}\right]$-gratisin was synthesized by conventional methods. Boc-D-Tyr $\left(\mathrm{BzlCl}_{2}\right)$ Val-Orn(Z)-Leu-D-Phe-Pro-OBzl (1) was obtained by the stepwise elongation from Pro-OBzl with the help of 1-ethyl-3-(3-dimethylaminopropyl)-
Fig. 1.

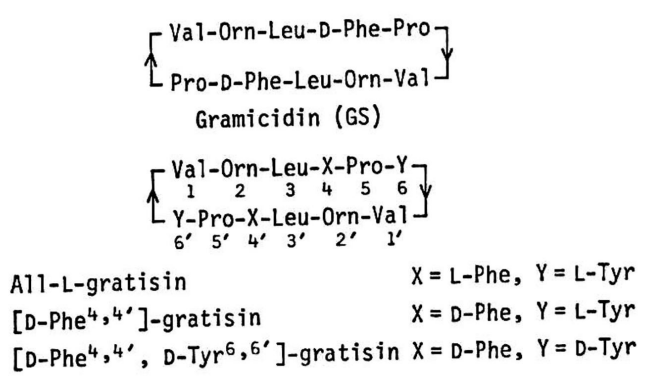

carbodiimide (WSCD) and 1-hydroxybenztriazole. A part of 1 was converted to the hydrazide. Coupling of the Boc-hexapeptide hydrazide and hexapeptide ester derived from 1 was carried out by an azide method to afford Boc(D-Tyr $\left(\mathrm{BzlCl}_{2}\right)$ - Val-Orn(Z) - Leu -D - Phe-Pro) ${ }_{2}$ OBzl. This ester was converted into the corresponding hydrazide, which was treated with $\mathrm{HCl} /$ dioxane and then cyclized by the azide method in pyridine. The yield of cyclization was $63 \%$. The protected groups of cyclododecapeptide were removed by hydrogenolysis to afford [D-Phe ${ }^{4,4^{\prime}}, \mathrm{D}-\mathrm{Tyr}^{8,6^{\prime}}$ ]-gratisin. The homogeneity of $\left[\mathrm{D}-\mathrm{Phe}^{4,4^{\prime}}, \mathrm{D}-\mathrm{Tyr}^{6,6^{\prime}}\right]$-gratisin was confirmed by means of thin-layer chromatography, electrophoresis, amino acid analysis and elemental analysis.

The antibiotic activity of [D-Phe $\left.{ }^{4,4^{\prime}}, \mathrm{D}-\mathrm{Tyr}^{8,8^{\prime}}\right]$ gratisin was examined toward several microorganisms (Table 1). [D-Phe $\left.{ }^{4,4^{\prime}}, \mathrm{D}-\mathrm{Tyr}^{8,8^{\prime}}\right]$-gratisin had antibiotic activity against all Gram-positive microorganisms tested, and its activity was the same as that of GS against $B$. subtilis and stronger than that of $\left[\mathrm{D}-\mathrm{Phe}^{4,4^{\prime}}\right]$-gratisin. These results suggest that -D-Phe-Pro- sequence plays an

Table 1. Antibiotic activities of GS and synthetic peptides.

\begin{tabular}{|c|c|c|c|c|}
\hline \multirow[b]{2}{*}{ Test organisms } & \multicolumn{4}{|c|}{ Minimum inhibitory concentration $(\mu \mathrm{g} / \mathrm{ml})$} \\
\hline & GS & All-L-gratisin & [D-Phe $\left.{ }^{4,4^{\prime}}\right]$-gratisin & $\begin{array}{c}\text { [D-Phe }{ }^{4,4^{\prime}}, \text { D-Tyr }{ }^{\left.6,6^{\prime}\right]-} \\
\text { gratisin }\end{array}$ \\
\hline Staphylococcus aureus ATCC 6538P & 1.6 & $>50$ & 50 & 6.3 \\
\hline Streptomyces pyogenes N.Y.5 & 1.6 & $>50$ & 12.5 & 3.1 \\
\hline Micrococcus flavus ATCC 10240 & 0.8 & 25 & 12.5 & 3.1 \\
\hline Corynebacterium diphtheriae P.W. 8 & 0.8 & 25 & 3.1 & 3.1 \\
\hline Bacillus subtilis ATCC 6633 & 3.1 & $>50$ & 50 & 3.1 \\
\hline Escherichia coli NIHJ-JC2 & $>100$ & $>50$ & $>50$ & $>50$ \\
\hline Proteus vulgaris OX 19 & $>100$ & $>50$ & $>50$ & $>50$ \\
\hline
\end{tabular}

Abbreviations with no prefix show L-amino acid residue. The following are from J. Biol. Chem. 247: 977 983, 1972: Boc-, $t$-butoxycarbonyl; Z-, benyloxycarbonyl; BzlCl$_{2-}$, 2,6-dichlorobenzyl. 
important role for antibiotic activity, and DTyr residue following Pro residue contributes to the activity.

In order to investigate the relationship between structure and antibiotic activity, the $C D$ spectrum of [D-Phe $\left.{ }^{4,4^{\prime}}, \mathrm{D}-\mathrm{Tyr}^{8,8^{\prime}}\right]$-gratisin in aqueous solution was determined. This spectrum showed a trough at $200 \mathrm{~nm}$ and a shoulder at $215 \mathrm{~nm}$, and the pattern was similar to that of random coils in proteins. On the other hand, the spectra of allL- and [D-Phe ${ }^{4,4^{\prime}}$ ]-gratisin were similar to that of GS.4)

We have had no opportunity to compare our synthetic preparations with natural gratisin. However, our investigation suggests that the synthetic peptide with D-residues in positions $4,4^{\prime}, 6$ and $6^{\prime}$ is identical with the natural product.

\section{Acknowledgment}

We are grateful to members of the Research Laboratories of Toyo Jozo Co. for their elemental analyses and antibiotic assays. We also thank $\mathrm{Mr}$. Y. Sugimura, Toho University, Department of Biology, for the amino acid analyses.

\section{MAKOTO TAMAKI \\ MichIAKI TAKIMOTO \\ *SHosuke Sofuku \\ *IChIRo Muramatsu}

Department of Chemistry, Faculty of Science, Toho University, Miyama, Funabashi-shi, Chiba, Japan

*Department of Chemistry, College of Science, Rikkyo (St. Paul's) University,

Nishi-ikebukuro, Tokyo, Japan

(Received February 2, 1983)

\section{References}

1) Zharikova, G. G.; S. P. Myaskovskaya \& A. B. SLIAEv: Antibiotic gratisin derived from the cells of the mutant Bacillus brevis strain Y-33. Vestn. Mosk. Univ. Biol. Pochvoved. 27: 110 112,1972

2) Myaskovskaya, S. P.; G. G. Zharikova \& A. B. SILAEv: Amino acid composition and some of the physicochemical properties of gratisin. Vestn. Mosk. Univ. Biol. Pochvoved. 28: 123 125,1973

3) Zharikova, G. G.; A. P. Zarubina, D. M. Kherat, S. P. MyasKovsKaya \& V. N. MaksIMOV: Formation of polypeptide antibiotics by spontaneous and induced mutants of Bacillus brevis var. G.-B. Antibiotiki IKh Produtsenty 1975: $163 \sim 186,1975$

4) Tamaki, M.; M. Takimoto, S. Sofuku \& I. Muramatsu: Synthetic studies on gratisin. J. Antibiotics 34: 1227 1228, 1981 